\title{
Species Composition and Stand Structure of Primary and Secondary Moist Evergreen Forests in the Tanintharyi Nature Reserve (TNR) Buffer Zone, Myanmar
}

\author{
Idd Idd Shwe Zin ${ }^{*}$, Ralph Mitlöhner² \\ ${ }^{1}$ University of Forestry and Environmental Science, Yezin, Nay Pyi Taw, Myanmar \\ ${ }^{2}$ Department of Tropical Silviculture and Forest Ecology, Georg-August University, Goettingen, Germany \\ Email: *iddiddshwezin02@gmail.com
}

How to cite this paper: Zin, I. I. S., \& Mitlöhner, R. (2020). Species Composition and Stand Structure of Primary and Secondary Moist Evergreen Forests in the Tanintharyi Nature Reserve (TNR) Buffer Zone, Myanmar. Open Journal of Forestry, 10, 445-459.

https://doi.org/10.4236/ojf.2020.104028

Received: August 27, 2020

Accepted: October 27, 2020

Published: October 30, 2020

Copyright $\odot 2020$ by author(s) and Scientific Research Publishing Inc. This work is licensed under the Creative Commons Attribution International License (CC BY 4.0).

http://creativecommons.org/licenses/by/4.0/

\begin{abstract}
The habitat structure and floristic composition examined for this study are of great importance, providing a scientific baseline of information for developing a biodiversity database and in supporting crucial information for the management decision-making process of the buffer zones. The primary objective of this study was to examine the current status of species composition and stand structure of moist evergreen forests distributed in the TNR buffer zone. Forest inventory was conducted in the primary moist evergreen forest $(\sim 1 \mathrm{ha})$ and secondary moist evergreen forest $(\sim 1 \mathrm{ha})$. In the TNR buffer zone, 83 species belonging to 31 families in the primary moist evergreen forest and 86 species belonging to 32 families in the secondary moist evergreen forest were found. The most dominant families in the primary moist evergreen forest were Dipterocarpaceae, Sapindaceae, Meliaceae, Myrtaceae, and Myristicaceae; at species level; this forest was composed of Nephelium lappaceum, Myristica malabarica, Nephelium laurium, Aglaia andamanica, and Diospyros peregrine. The most dominant families in the secondary moist evergreen forest were Myrtaceae, Sapindaceae, Euphorbiaceae, Myristicaceae, and Lauraceae, while Nephelium lappaceum, Syzygium claviflorum, Syzygium sp-1, Eugenia oblate, and Myristica angustifolia were the most dominant at the species level. The results of Sörensen's similarity index based on common species (Ks) and the similarity index based on species dominance (Kd) were observed at about $55 \%$ and $75 \%$ between the primary and secondary moist evergreen forests. The basal area $\left(51.39 \mathrm{~m}^{2} \cdot \mathrm{ha}^{-1}\right)$ of the primary moist evergreen forest was higher than that $\left(44.50 \mathrm{~m}^{2} \cdot \mathrm{ha}^{-1}\right)$ of the secondary moist evergreen forest. Between these two forest types, the Shannon-Wiener,
\end{abstract}


the Simpson and the Evenness indices were not significantly different at ( $\mathrm{p}<$ $0.05)$. The total number of trees per hectare $(\mathrm{n} / \mathrm{ha})$ of the primary and secondary moist evergreen forests were $910( \pm 184)$ and $991( \pm 183)$.

\section{Keywords}

Tree Density, Basal Area, Floristic Similarity Index, Floristic Composition, Moist Evergreen Forest

\section{Introduction}

Tropical rain forests occur in the southernmost portion of Myanmar. These are the most structurally complex plant communities and are the richest in species in Myanmar (Kermode, 1964). The primary objective of this study is to highlight tree species diversity, species composition and stand structure of tropical rain forests which support the sustainable forest management in Myanmar.

Forest types and their distribution are dominated by geological factors (soil and slope), rainfall regimes, and species associations (Kyaw, 2003). Due to human intervention, agricultural expansion and biogeography, species diversity in tropical forests differ greatly from location to location (Whitmore, 1998). Floristic inventory is a prerequisite to assess the current diversity to inform the conservation of forest biodiversity (Jayakumar et al., 2011). The expression of stand density across different diameter class distributions showed how the forest is adapting to dynamic environmental conditions. For a more detailed analysis of stand structure, more information is needed on the actual distribution of diameters in the stand and the absolute distribution of stem numbers per diameter class (Apel, 1996).

\section{Materials and Methods}

\subsection{Study Area}

This study was carried out in the ecologically and administratively distinct areas of Tanintharyi Nature Reserve, the Tanintharyi Division (Figure 1). Tanintharyi Nature Reserve is situated between latitudes $14^{\circ} 20^{\prime} 50^{\prime \prime}$ and $14^{\circ} 57^{\prime} 55^{\prime \prime}$ North and between longitudes $98^{\circ} 5^{\prime} 10^{\prime \prime}$ and $98^{\circ} 31^{\prime} 32^{\prime \prime}$ East. Tanintharyi Nature Reserve (TNR) was legally established by the Ministry of Environmental Conservation and Forestry (MOECAF) in 2005 as a protected area. It is situated between the Dawei River and the Myanmar-Thailand border. It includes 170,000 ha with primarily pristine tropical evergreen forest and some mixed deciduous forest. It lies in the Ecoregion of Tenasserim-South Thailand Semi-Evergreen Rain Forests and harbors globally outstanding levels of species richness (WWF, 2002). In the Tanintharyi Division, forest inventory was conducted in the buffer zone of Tanintharyi Nature Reserve (TNR). We highlighted the species composition and stand structure of primary and secondary forests in the TNR buffer zone areas. 


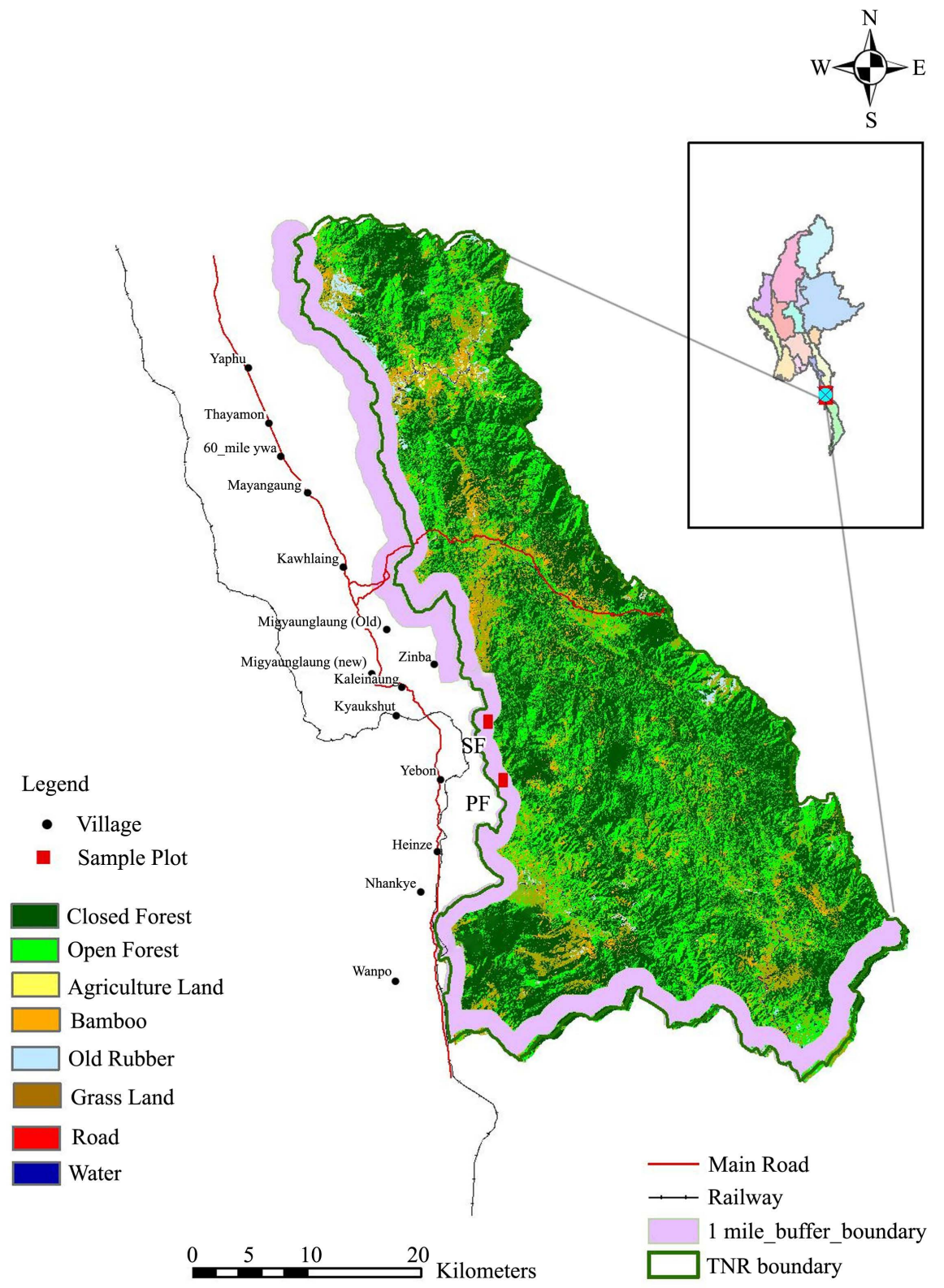

SF (Secondary Moist Evergreen Forest), PF (Primary Moist Evergreen Forest)

Figure 1. Location of the study sites in Tanintharyi Nature Reserve, Southern Myanmar. Source: GIS, Forest Department (FD).

Based on the past ten years of climatic data from the Department of Meteorology and Hydrology (Meteorology Department of Dawei Township, 2014), the mean annual temperature was $28^{\circ} \mathrm{C}$ with the hottest in March and the coldest in January, while the mean annual rainfall was $5519 \mathrm{~mm}$. This area is among the most abundant rainfall areas in Myanmar because the climate is seasonal and monsoon type.

\subsection{Field Surveys}

In Figure 1, two different sites were chosen in the buffer zone areas of TNR. 
There were 25 sample plots measuring $20 \mathrm{~m} \times 20 \mathrm{~m}$ (one hectare) with equal intervals (200 $\mathrm{m}$ in distance) in each site due to the heterogeneity of sites in the nature reserve. The aim was to obtain the representative tree species in the different ecosystems and to support a quantitative estimate of plant species diversity. Height and diameter at breast height $(\mathrm{DBH} \geq 5 \mathrm{~cm})$ of all trees were measured in each plot for the two study sites.

\subsection{Data Analysis}

All data were put into Microsoft Excel 2013 spreadsheets and later transferred to Statistica software version 12.5. The relative abundance, relative frequency, and dominance were used to calculate the Importance Value Index at the family and species levels, characterizing the composition and diversity of tree species (Curtis \& McIntosh, 1951; Greig-Smith, 1983; Mori et al., 1983; Lamprecht, 1989). Sörensen's Coefficient of Similarity method was applied to identify the similarity ratio among forest stands (Magurran, 1988; Lamprecht, 1989).

The species richness is the number of species appearing within a specific forest area (Magurran, 1988). The Simpson index $(1-D)$ gives was calculated according to Magurran (1988) as follows:

$$
\left(1-D^{\prime}\right)=1-\sum_{i=1}^{S} P_{i}^{2}
$$

where: $S$ : the number of species and

$P_{i}$ : the proportion of individuals belonging to each species

The Shannon-Wiener index $\left(H^{\prime}\right)$ is the most widely used index for comparing diversity between habitats (Clarke \& Warwick, 1994). The Shannon-Wiener index was calculated according to (Clarke \& Warwick, 1994) as follows:

$$
H^{\prime}=-\sum_{i=1}^{S} P_{i} \times \ln P_{i}
$$

where: $P_{i}$ : the density of a species and

$P$ : sum of total density of all species in that forest type and

$S$ : the number of species.

The Evenness index $(J)$ expresses how evenly individuals are distributed among different species (Khan, 2006); it was calculated according to Pielou (1966) as follows:

$$
J^{\prime}=\frac{H^{\prime}}{\ln (S)}
$$

where: $H^{\prime}=$ Shannon-Wiener index and

$S=$ the number of species.

\section{Results}

\subsection{Species Areas Relationship}

The species-area curve is the best statistical indicator for detecting the habitat diversity within the survey area (He \& Legendre, 1996), and was used to determine a minimum plot-size needed to survey a community adequately (Lam- 
precht, 1989). In this study, species-area curves (Figure 2) were drawn based on trees that attained $\geq 1.3 \mathrm{~m}$ in height and $\geq 5 \mathrm{~cm}$ dbh and the total area was one hectare for each forest type. In the buffer zone, the curves of primary forest and secondary forest were greater and reached as high as $4800 \mathrm{~m}^{2}$. After that the secondary forest increased more than primary forest at $7600 \mathrm{~m}^{2}$ and its curve appeared constant from the point of $9200 \mathrm{~m}^{2}$. Because of human interventions in the secondary forest, different sizes of gaps are formed and different tree species are known to respond to or regenerate in these areas. Moreover, the primary forest gradually increased and become constant at $9600 \mathrm{~m}^{2}$. As suggested by Cain (1938) and Lamprecht (1989), the minimum area is acceptable when the occurrence of new species remains below $10 \%$ with a $10 \%$ expansion in the sample area. The trend curves of all forests indicated that the total survey area (one hectare) can be regarded as a representative for tree flora in the buffer zone of TNR.

\subsection{Species Richness and Diversity}

The species richness of trees $(\mathrm{DBH} \geq 5 \mathrm{~cm}$ ) showed that the secondary forest occupied the greatest number of species (86) and families (32) in the buffer zone of TNR whereas the primary forest possessed the number of species (83) and families (31) (Table 1). In the buffer zone, it was found that Shannon's diversity index, the Simpson's index and the Shannon evenness were not significantly different between two sites $(p<0.05)$ (Figure 3$)$. The species richness was not significantly different between primary forest and secondary forest in the buffer zone when the parametric statistical analysis (Two Samples t-test for primary $(15.52 \pm 3.2)$ and secondary $(16.52 \pm 3.5)$ forests in TNR, Independent Samples $t$-Test) was used to compare the mean value species richness at the subplot level of the two forest types (Figure 4). The primary forest possessed higher arithmetic mean diameter value than did of the secondary forest in the buffer zone (Table 1).

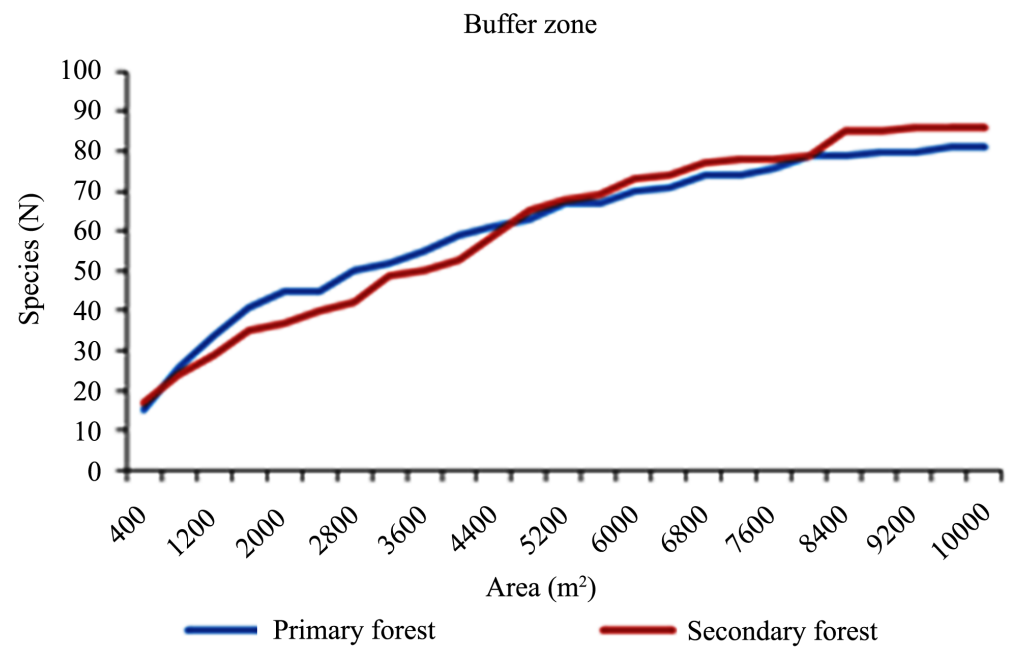

Figure 2. The relationship curves of species-areas in two forests of TNR buffer zone. 


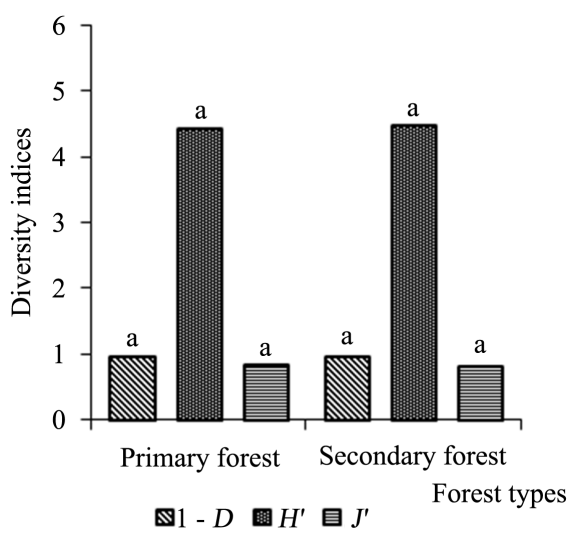

Figure 3. A comparison of species diversity of all stems with a $\mathrm{DBH} \geq 5 \mathrm{~cm}$ between the two forest types. The small letter "a" indicates no significant differences (Mann-Whitney U test).

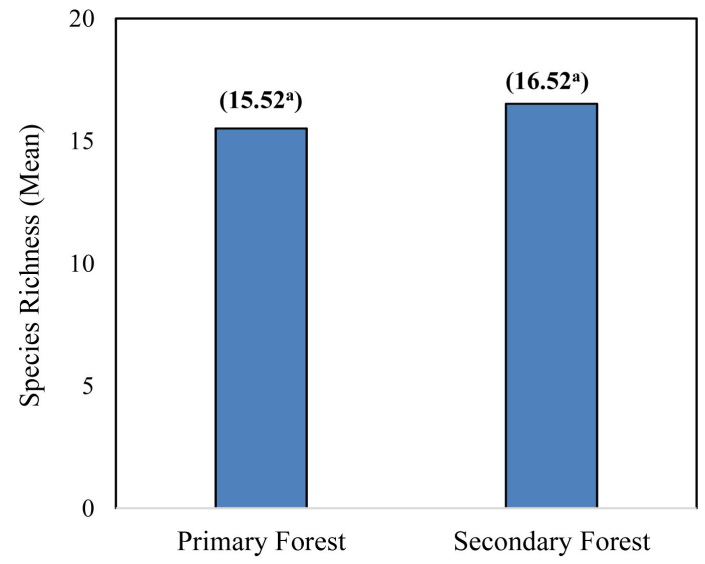

Figure 4. A comparison of species richness of all stems with a $\mathrm{DBH} \geq 5 \mathrm{~cm}$ between the two forest types. The lowercase letter "a" indicates no significant differences (Two Sample t-test for primary $(15.52 \pm 3.2)$ and secondary $(16.52 \pm 3.5)$ forests in TNR, Independent Samples t-Test).

Table 1. Summary of tree diversity parameters $(\mathrm{DBH} \geq 5 \mathrm{~cm})$ in the primary and secondary forests of the TNR buffer zone.

\begin{tabular}{ccc}
\hline Variable & \multicolumn{2}{c}{ Buffer zone } \\
\cline { 2 - 3 } Density/ha(n) & Primary forest & Secondary forest \\
Basal area/ha $\left(\mathrm{m}^{2}\right)$ & $910 \pm 184$ & $991 \pm 183$ \\
Arithmetic mean diameter $(\mathrm{cm})$ & $51.39 \pm 21.64$ & $44.50 \pm 20.00$ \\
Family richness & $18.2 \pm 19.7$ & 32 \\
Species richness & 31 & 86 \\
Simpson's diversity index $(1-\mathrm{D})$ & 83 & 0.95 \\
Shannon-Weiner (H') & 0.96 & 4.45 \\
Shannon evenness (\%) & 4.42 & 80 \\
Elevation above sea level (m) & 82 & $273-336$
\end{tabular}




\subsection{Dominant Species and Families}

The Family Importance Value (FIV) was calculated following Mori et al. (1983). This IVI index is a combination of the relative dominance, relative abundance, and the relative frequency of all plant families in a particular stand. In this study, the index IVI developed by Curtis and McIntosh (1951) was used to describe species composition. In the primary forest of buffer zone, Dipterocarpaceae was ranked first in terms of dominance $\left(13.44 \mathrm{~m}^{2} \cdot \mathrm{ha}^{-1}\right)$ and Sapindaceae was highest in tree abundance (184 individuals). Meliaceae ranked second in absolute dominance $\left(7.96 \mathrm{~m}^{2} \cdot \mathrm{ha}^{-1}\right)$. At the secondary forest of buffer zone, Myrtaceae had the highest dominance $\left(13.95 \mathrm{~m}^{2} \cdot \mathrm{ha}^{-1}\right)$. Sapindaceae was the highest in terms of trees abundance (212 individuals) and dominance $\left(8.09 \mathrm{~m}^{2} \cdot \mathrm{ha}^{-1}\right)$.

In the primary forest of buffer zone (Table 2), Nephelium lappaceum had the high abundance ( 93 trees $\mathrm{ha}^{-1}$ ) and absolute frequency (80\%) with highest importance value (21.2\% of the total IVI). Myristica malabarica and Nephelium laurium were the second and third dominant species with the importance values of $18.0 \%$ and $15.7 \%$. Aglaia andamanica ranked the fifth in highest absolute dominance $\left(5.13 \mathrm{~m}^{2} \cdot \mathrm{ha}^{-1}\right)$, in absolute frequency $(48 \%)$, and contributed about $15.6 \%$ of the total IVI. Michelia champaca and Shorea cinerea were followed by the second and third positions in absolute dominance of $4.81 \mathrm{~m}^{2} \cdot \mathrm{ha}^{-1}$ and 3.80 $\mathrm{m}^{2} \cdot \mathrm{ha}^{-1}$ with the importance values of $13.2 \%$ and $10.6 \%$. The top twelve species of this forest type formed a little more than half values of the total value IVI (158\%). Nephelium lappaceum was the most dominant species in the secondary forest with highest species importance value (33.9\%) due to the highest absolute dominance and in abundance ( 148 trees $\left.\mathrm{ha}^{-1}\right)$. Eugenia oblate with $15.8 \%$ of total importance value ranked the second in absolute dominance $\left(4.17 \mathrm{~m}^{2} \cdot \mathrm{ha}^{-1}\right)$. The next two dominant species were Syzygium claviflorum (17.0\% of the total IVI) and Syzygium sp ${ }^{-1}$ (16.5\% of the total IVI), respectively represented by 48 and 65 individuals with absolute frequencies of $64 \%$ and $80 \%$. Therefore, Nephelium lappaceum, Syzygium claviflorum, Swintonia floribunda and Diospyros peregrine were the common species in the primary forest and secondary forest.

In Figure 5, the basal area of the primary forest (with 910 trees) was higher than those of the secondary forest with the highest number of stems (991 trees). In the primary forest, these areas had higher basal areas due to the presence of numerous large trees with large diameters (e.g., Michelia champaca and Parashorea stellate). In the primary forest of the buffer zone, Dipterocarpaceae was ranked first in terms of dominance $\left(13.4 \mathrm{~m}^{2} \cdot \mathrm{ha}^{-1}\right)$ with number of species (9). Sapindaceae had the highest tree abundance (184 individuals) with the number of species (3) whereas Magnoliace has the only tree species with the dominance $\left(4.81 \mathrm{~m}^{2} \cdot \mathrm{ha}^{-1}\right)$. Meliaceae ranked second in absolute dominance $\left(7.96 \mathrm{~m}^{2} \cdot \mathrm{ha}^{-1}\right)$. In the secondary forest (Figure 6), Myrtaceae had the highest dominance (13.95 $\mathrm{m}^{2} \cdot \mathrm{ha}^{-1}$ ) with the number of species (6). Sapindaceae was the highest in terms of tree abundance (212 individuals) and dominance $\left(8.09 \mathrm{~m}^{2} \cdot \mathrm{ha}^{-1}\right)$ with the number of species (4). Sterculiaceae had only one tree species. 
Table 2. The twelve most importance tree species (IVI) of two different types in the TNR buffer zone (all stems with a DBH $\geq 5 \mathrm{~cm}$ ).

\begin{tabular}{|c|c|c|c|c|c|}
\hline \multirow[b]{2}{*}{ No } & \multirow[b]{2}{*}{ Species } & \multicolumn{3}{|c|}{ Absolute } & \multirow{2}{*}{$\begin{array}{l}\text { IVI } \\
(\%)\end{array}$} \\
\hline & & $\begin{array}{c}\text { Abundance } \\
\left(\mathrm{n} \cdot \mathrm{ha}^{-1}\right)\end{array}$ & $\begin{array}{l}\text { Dominance } \\
\left(\mathrm{m}^{2} \cdot \mathrm{ha}^{-1}\right)\end{array}$ & $\begin{array}{c}\text { Frequency } \\
(\%)\end{array}$ & \\
\hline \multicolumn{6}{|c|}{ Primary Forest } \\
\hline 1 & Nephelium lappaceum & 93 & 2.98 & 80 & 21.2 \\
\hline 2 & Myristica malabarica & 80 & 2.60 & 64 & 18.0 \\
\hline 3 & Nephelium laurium & 72 & 1.88 & 64 & 15.7 \\
\hline 4 & Aglaia andamanica & 23 & 5.13 & 48 & 15.6 \\
\hline 5 & Diospyros peregrina & 61 & 1.41 & 84 & 14.8 \\
\hline 6 & Michelia champaca & 19 & 4.81 & 28 & 13.2 \\
\hline 7 & Syzygium claviflorum & 43 & 1.98 & 60 & 12.4 \\
\hline 8 & Swintonia floribunda & 27 & 2.52 & 60 & 11.7 \\
\hline 9 & Amoora wallichii & 43 & 2.29 & 32 & 11.2 \\
\hline 10 & Shorea cinerea & 10 & 3.80 & 32 & 10.6 \\
\hline 11 & Dipterocarpus sp & 36 & 0.59 & 32 & 7.2 \\
\hline \multirow[t]{4}{*}{12} & Anisoptera scaphula & 4 & 2.52 & 16 & 6.4 \\
\hline & Other species & 399 & 18.89 & & 142.0 \\
\hline & Total & 910 & 51.39 & & 300.0 \\
\hline & \multicolumn{5}{|c|}{ Secondary Forest } \\
\hline 1 & Nephelium lappaceum & 148 & 5.98 & 92 & 33.9 \\
\hline 2 & Syzygium claviflorum & 48 & 3.69 & 64 & 17.0 \\
\hline 3 & Syzygium sp-1 & 65 & 2.27 & 80 & 16.5 \\
\hline 4 & Eugenia oblate & 35 & 4.17 & 48 & 15.8 \\
\hline 5 & Myristica angustifolia & 54 & 2.08 & 64 & 14.0 \\
\hline 6 & Callerya atropurpurea & 30 & 3.17 & 52 & 13.3 \\
\hline 7 & Syzygium buxifolium & 8 & 3.59 & 28 & 10.6 \\
\hline 8 & Theobroma sp & 54 & 0.62 & 52 & 10.0 \\
\hline 9 & Aporosa sp & 52 & 0.39 & 60 & 9.8 \\
\hline 10 & Swintonia floribunda & 16 & 2.05 & 40 & 8.7 \\
\hline 11 & Cinnamomum pachyphyllum & 20 & 1.57 & 40 & 7.9 \\
\hline \multirow[t]{3}{*}{12} & Diospyros peregrine & 36 & 0.44 & 52 & 7.8 \\
\hline & Other species & 425 & 14.47 & & 134.7 \\
\hline & Total & 991 & 44.50 & & 300.0 \\
\hline
\end{tabular}


Primary Forest

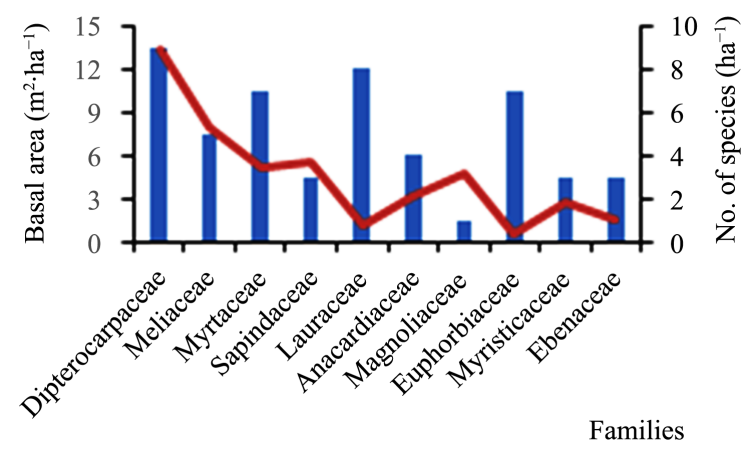

Figure 5. The basal area and no. of species of the individual family in the primary forest, TNR.

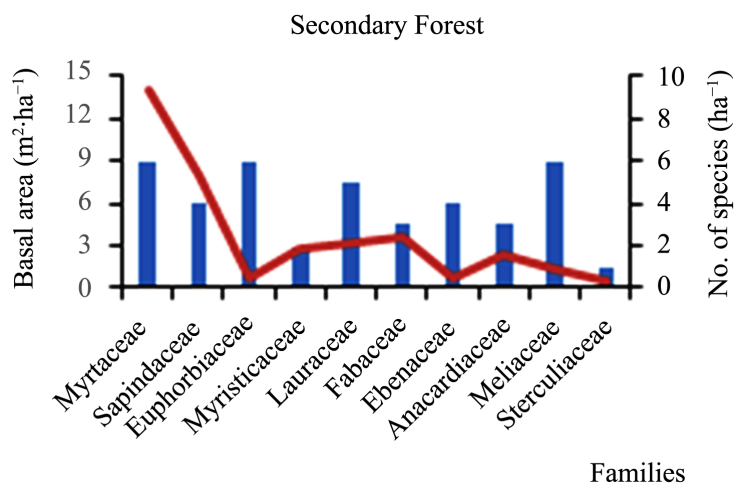

Figure 6. The basal area and no. of species of the individual family in the secondary forest, TNR.

\subsection{Species Richness Based on Diameter Class}

Species richness was classified into five diameter $(\mathrm{DBH})$ classes: $\leq 30 \mathrm{~cm}, 30-60$ $\mathrm{cm}, 60-90 \mathrm{~cm}, 90-120 \mathrm{~cm}$, and $\geq 120 \mathrm{~cm}$. The species recorded in the two forest types are given in Figure 7. More than $90 \%$ of species richness found in all sample plots in the two forest types was present in the smallest diameter class $(\leq 30$ $\mathrm{cm} \mathrm{DBH})$, while only $4.1 \%$ was recorded in the largest diameter class $(\geq 120 \mathrm{~cm}$ $\mathrm{DBH})$ in the primary forest; $2.3 \%$ of species richness was found in the secondary forest.

In the primary forest, Amoora wallichii, Diospyros peregrine, Dipterocarpus sp, Syzygium claviflorum, Myristica malabarica, Nephelium lappaceum, Nephelium laurium, and Xerospermum noronhianum were dominant species in the smallest diameter class $(\leq 30 \mathrm{~cm}$ DBH), while Parashorea stellata, Michelia champaca, and Amoora wallichii were recorded in the largest diameter class $(\geq 120 \mathrm{~cm} \mathrm{DBH})$. Cinnamomum pachyphyllum, Lithocarpus sp, Payena paralleloneura, Swintonia floribunda, and Shorea sp were mostly found in the $30-60$ cm diameter class, while Anisoptera scaphula, Eugenia oblate, Lithocarpus sp, Payena paralleloneura, Swintonia floribunda, and Shorea sp were recorded in the 60 - $90 \mathrm{~cm}$ diameter class. Dipterocarpus turbinatus, Shorea sp, and Swintonia floribunda were found in the $90-120 \mathrm{~cm}$ diameter class. 


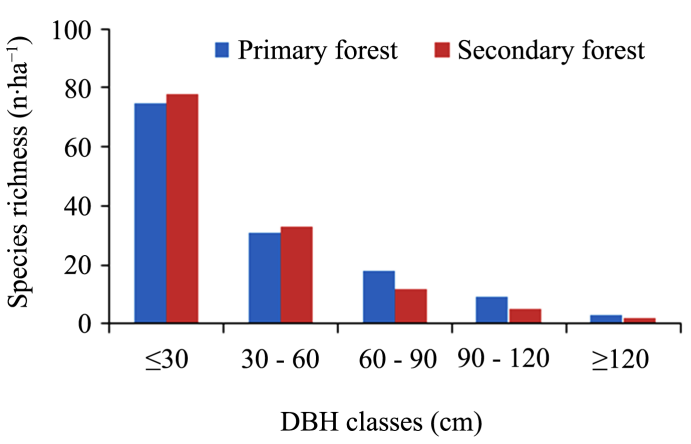

Figure 7. Species richness of all stems with a $\mathrm{DBH} \geq 5 \mathrm{~cm}$ based on diameter classes between the two forest types in the TNR buffer zone.

In the secondary forest, Amoora wallichi, Aporosa sp, Myristica angustifolia, Nephelium lappaceum, Nephelium sp-1, Syzygium sp-1, Theobroma sp, Barringtonia cymosa, and Diospyros peregrine mostly occurred in the smallest diameter class ( $\leq 30 \mathrm{~cm} \mathrm{DBH).} \mathrm{Amoora} \mathrm{wallichi,} \mathrm{Eugenia} \mathrm{oblata,} \mathrm{Myristica} \mathrm{angus-}$ tifolia, Nephelium lappaceum, Syzygium claviflorum, and Syzygium sp-1 were dominant species in the $30-60 \mathrm{~cm}$ diameter class; Callerya atropurpurea, Cinnamomum pachyphllum, Eugenia oblate, Naphelium sp-2, Nephelium lappaceum, and Syzygium buxifolium were mostly found in the $60-90 \mathrm{~cm}$ diameter class. Nephelium lappaceum, Dalbergia fusca, Syzygium buxifolium and Syzygium claviflorum, occurred in the larger, $90-120 \mathrm{~cm}$ diameter class, while the two largest trees (Eugenia oblata and Swintonia floribunda) were the only specimens in the $\geq 120 \mathrm{~cm} \mathrm{DBH}$ class. In this study, this trend could be modeled by a simple reverse J-shape relationship. This study's differences in the distribution of species richness across various DBH classes were found between the two forest types.

\section{Discussion}

\section{1) Species richness and diversity}

In the study, the species area curves showed that one hectare was used as a representative area for accessing of tree flora in two forest types of buffer zone areas in TNR. Tree species richness is highly diverse in the tropical rain forest (Phillips et al., 1994). In the buffer zone area of TNR, species richness ranged from 83 to 86 (with $\mathrm{DBH} \geq 5 \mathrm{~cm}$ ) in the two different forest types and the number of species in the secondary forest was higher than that of primary forest. In addition, a total of 83 species belonging to 30 families in the primary and a total of 86 species belonging to 33 families in the secondary forest were observed in the TNR buffer zone. The range of tree species count per hectare in tropical rain forest is about 20 to a maximum of 223 (Whitmore, 1984). The secondary forest had been deforested due to logging and caused gap opening which favors new species and increased species diversity. Therefore, the secondary forest possessed the higher species number per hectare. The number of species recorded in the secondary forest was consistent with the number of species reported by Cam, 
2015 in the Least Impact Forest (LIF) and High Impact Forest (HIF) in the Kon Ha Nung region of Vietnam's Central Highlands, whereas the number of species in the primary forest in this study was higher than the unlogged forest in the Kon Ha Nung region of Central Highlands in Vietnam (Cam, 2015) whereas the results of primary and secondary forests in the present study were lower than the number of species recorded on the limestone forest of Cat Dua Island, North-Eastern Vietnam (Qin et al., 2012).

Based on the results of the species richness, Simpson's index, and ShannonWiener's index, both forest types had high species diversity The Shannon-Wiener for the primary forest and the secondary forest were 4.419 and 4.454 respectively. In two forest sites, the Simpson index $(1-D)$ ranged from 0.953 to 0.959 where from 0.803 to 0.824 was found in the Evenness index. Shannon-Wiener's index and evenness index of species are found to be higher in the study sites when compared with other study areas of moist evergreen forests in Kyeikhtiyo Wildlife Sanctuary, Mon State, Myanmar (Thu, 2009) and the differently logged moist evergreen forests in Huong Son-Vu Quang of Vietnam (Hung, 2008). This result showed that the secondary forest was the most complex in terms of species diversity and species composition. The secondary forest is the most heterogeneous site because it is near the village tracts (Kyaukshut) and consequently highly prone to forest fires and illegal logging (Zin, 2017). At the present, Kyaukshut village depends on water sources from this secondary forest. The growth condition shows very good status in this study as the primary forest and it gives rise to the presence of more species compared to two other sites in the core zone and buffer zone areas (Thein, 2007). Richards, 1996 described that the species richness found in $1-2$ hectare plots in old secondary forest was higher than that of primary forest in the same region, but this was not always true when the investigation area was extended.

\section{2) Species composition, dominant species and families}

Importance value index (IVI) showed that Dipterocarpaceae, Sapindaceae, Meliaceae and Myrtaceae were the most dominant families in the primary forest while the most dominant families were Myrtaceae Sapindaceae, Euphorbiaceae, Myristicaceae in the secondary forest. At the species level, Nephelium lappaceum, Myristica malabarica, Nephelium laurium, Aglaia andamanica, Diospyros peregrine and Michelia champaca in the primary forest and Nephelium lappaceum, Syzygium claviflorum, Syzygium sp-1, Eugenia oblate and Myristica angustifolia in the secondary forest were the dominant species in the TNR buffer zone. The species composition was different between the two forest types in the buffer zone due to different elevations, soil nutrients, natural disturbances such as forest fire, heavy rainfall and artificial disturbances such as illegal logging and shifting cultivation. Changes in species compositions and diversity depend on micro-environmental conditions such as geography, location, climatic, altitude, soil characteristics, and human interventions and disturbances (Neumann \& Starlinger, 2001; Padalia et al., 2004; Mani \& Parthasarathy, 2006). 


\section{3) Species similarity, basal area and tree density}

In Table 3, the results of Sörensen's index of Similarity (Ks) and the similarity index based on species dominance $(\mathrm{Kd})$ showed that the highest degree of floristic similarity (Ks) (55.62\%) and similarity coefficient (Kd) (75.30\%) was recorded between primary forest and secondary forest because most of species in the primary forest and secondary of buffer zone are similar to each other. However, primary forest had the higher basal area $\left(51.39 \mathrm{~m}^{2} \cdot \mathrm{ha}^{-1}\right)$ with stand density (910 stems) due to the presence of many large trees with greatest diameters, such as Michelia champaca and Parashorea stellata with high basal areas. Likewise, secondary forest possessed the second highest basal area $\left(44.50 \mathrm{~m}^{2} \cdot \mathrm{ha}^{-1}\right)$ due to the highest stand densities (991 stems) and the presence of few numbers of big stems. However, all forest stands possessed different number of stems and basal areas but their structures were similar in the population. The basal area of primary forest was lower than that of the lowland rain forests, with 739 stems ha $^{-1}$ in Gunung of Mulu, Sarawak, Malaysia (Proctor et al., 1983). Both the secondary forest and primary forest had higher basal areas than lowland rain forest, with 592 stems ha $^{-1}$ in Borneo, Indonesia (Sukardjo et al., 1990).

\section{4) Diameter classes distribution}

In the study, the primary forest has a distinct feature that includes very large stems that grow taller than those in the secondary forests, despite similar site conditions (Richards, 1996). An abundance of large stems was recorded in the primary forest and secondary forest of TNR and they have a reverse J shape forms and similar trend of diameter distribution. These results are consistent with Thu's findings (2009) in the moist evergreen dipterocarp forests in Kyeikhtiyo Wildlife Sanctuary in Mon State, Myanmar and the diameter distributions of tropical moist evergreen forests in the North and Central Highland regions of Vietnam (Pham, 2008; Pham, 2012; Cam, 2015). In the primary forest, the recorded species such as (Parashorea stellata, Michelia champaca and Amoora wallichi) with $\mathrm{DBH} \geq 120 \mathrm{~cm}$ were mostly commercial tree species. In both forest types, some of the commercial tree species such as Dipterocarpus turbinatus, Shorea sp in the primary forest and Dalbergia fusca and Syzygium claviflorum in the secondary forest were found. These results are similar to Thu's findings (2009) in the moist evergreen dipterocarp forests in Kyeikhtiyo Wildlife Sanctuary in Mon State, Myanmar.

\section{Conclusion}

In the TNR buffer zone, 83 species belonging to 31 families in the primary forest

Table 3. Floristic similarity among the investigated stands in the TNR buffer zone (all stem with a $\mathrm{DBH} \geq 5 \mathrm{~cm}$ ).

\begin{tabular}{ccc}
\hline Coefficient of Similarity & Values (\%) & Remark \\
\hline Ks (Sörensen, 1948) & 55.62 & Based on number of species \\
Kd (Lamprecht,1989) & 75.3 & Based on dominance of species
\end{tabular}


and 86 species belonging to 32 families in the secondary forest were found. The greatest basal area $\left(51.39 \mathrm{~m}^{2} \cdot \mathrm{ha}^{-1}\right)$ was found in the primary moist evergreen forest. However, the secondary moist evergreen forest possessed higher diversity values than those of the primary moist evergreen forest. The tree community in the secondary moist forest would therefore be expected to return to close to its previous species composition. The floristic structure was largely similar between primary forest and secondary forest in the TNR buffer zone.

\section{Acknowledgements}

I would like to express my sincere gratitude to Prof. Dr. Ralph Mitlöhner (Department of Tropical Silviculture and Forest Ecology, University of Goettingen, Germany) for his scientific guidance, valuable ideas and kindly support throughout the study. The study was financed by a German Academic Exchange Service (DAAD) scholarship. My special thanks go to my great friend, Dr. Ngo Van Cam and my student, Yin Min Thant (UFES) who help me in various ways.

\section{Conflicts of Interest}

The authors declare no conflicts of interest regarding the publication of this paper.

\section{References}

Apel, U. (1996). Der Dorfwald von Moxie: Traditionelle Dorfwaldbewirtschaftung in Xishuangbanna, Sudwest-China. Goettinger Beitraege zur Land-und Forstwirtschaft in den Tropen und Subtropen 108.

Cain, S. A. (1938). The Species-Area Curve. American Midland Naturalist, 19, 537-581. https://doi.org/10.2307/2420468

Cam, N. V. (2015). Long Term Impacts of Logging Intensity on Forest Structure and Stand Dynamics of Tropical Evergreen Broad-Leaved Forests in Kon Ha Nung, Central Highlands of Vietnam. PhD Dissertation, Göttingen: University of Göttingen, Cuvillier Verlag.

Clarke, K. R., \& Warwick, R. M. (1994). Change in Marine Communities: An Approach to Statistical Analysis and Interpretation (144 p.). Swindon: Natural Environment Research Council, UK.

Curtis, J. T., \& McIntosh, R. P. (1951). An Upland Forest Continuum in the Prairie-Forest Border Region of Wisconsin. Ecology, 32, 476-496.

https://doi.org/10.2307/1931725

Greig-Smith, P. (1983). Quantitative Plant Ecology (3rd ed., 359 p.). Studies in Ecology Vol. 9, Oxford: Blackwell Scientific Publications.

He, F., \& Legendre, P. (1996). On Species-Area Relations. American Naturalist, 148, 719-737. https://doi.org/10.1086/285950

Hung, P. Q. (2008). Structure and Light Factor in Differently Logged Moist Forests in Huong Son-Vu Quang, Vietnam (145 p.). Dissertation, Göttingen: University of Göttingen, Cuvillier Verlag.

Jayakumar, S., Kim, S. S., \& Heo, J. (2011). Floristic Inventory and Diversity Assessment-A Critical Review. Proceedings of the International Academy of Ecology and Environmental Sciences, 1, 151-168. 
Kermode, C. W. D. (1964). Some Aspects of Silviculture in Burma Forests (162 p.). Rangoon: Central Press.

Khan, A. (2006). Methodology for Assessing Biodiversity (12 p.). Chidambaram: Centre of Advanced Study in Marine Biology, Annamalai University.

Kyaw, N. N. (2003). Site Influence on Growth and Phenotype of Teak (Tectona grandis Linn. f.) in Natural Forests of Myanmar (163 p.). PhD Dissertation, Göttingen: Der Georg-August-Universität Göttingen, Cuvillier Verlag.

Lamprecht, H. (1989). Silviculture in the Tropics: Tropical Forest Ecosystems and Their Tree Species-Possibilities and Methods for Their Long-Term Utilization (296 p.). Eschborn: Technical Cooperation-Federal Republic of Germany (GTZ).

Magurran, A. E. (1988). Ecological Diversity and Its Measurement (179 p.). Princeton, NJ: Princeton University Press. https://doi.org/10.1007/978-94-015-7358-0

Mani, S., \& Parthasarathy, N. (2006). Tree Diversity and Stand Structure in Inland and Coastal Tropical Dry Evergreen Forests of Peninsular India. Current Science, 90, 1238-1246.

Mori, S. A., Boom, B. M., de Carvalino, A. M., \& dos Santos, T. S. (1983). Ecological Importance of Myrtaceae in an Eastern Brazilian Wet Forest. Biotropica, 15, 68-70. https://doi.org/10.2307/2388002

Neumann, M., \& Starlinger, F. (2001). The Significance of Different Indices for Stand Structure and Diversity in Forests. Forest Ecology and Management, 145, 191-196. https://doi.org/10.1016/S0378-1127(00)00577-6

Padalia, H., Chauhan, N., Porwal, M. C., \& Roy, P. S. (2004). Phytosociological Observations on Tree Species Diversity of Andaman Islands, India. Current Science, 87, 799-806.

Pham, M. T. (2012). Structure and Regeneration of Lowland Tropical Moist Evergreen Forests in North and Central Vietnam (169 p.). PhD Dissertation. Göttingen: Georg-August-Universität Göttingen.

Pham, Q. H. (2008). Structure and Light Factor in Differently Logged Moist Forests in Vu Quang-Huong Son, Vietnam (120 p.). PhD Dissertation. Göttingen: Georg-August-Universität Göttingen.

Phillips, O. L., Hall, P., Gentry, A. H., Sawyer, S. A., \& Vasquez, R. (1994). Dynamics and Species Richness of Tropical Rain Forests. Proceedings of the National Academy of Sciences, 91, 2805-2809. https://doi.org/10.1073/pnas.91.7.2805

Pielou, E. C. (1966). The Measurement of Diversity in Different Types of Biological Colledions. Journal of Theoretical Biology, 13, 131-144.

https://doi.org/10.1016/0022-5193(66)90013-0

Proctor, J., Anderson, J. M., Fogden, S. C. L., \& Vallack, H. W. (1983). Ecological Studies in Four Contrasting Lowland Rain Forests in Gunung Mulu National Park, Sarawak: II. Litterfall, Litter Standing Crop and Preliminary Observations on Herbivory. The Journal of Ecology, 71, 261-283. https://doi.org/10.2307/2259976

Qin, X., Zhang, R., \& Xing, F. (2012). A Study on the Flora and Vegetation of Cat Dua Island, Norteastern Vietnam. Pakistan-Journal of Botany, 44, 1229-1232.

Richards, P. W. (1996). The Tropical Rain Forest: An Ecological Study (2nd ed.). Cambridge: Press Syndicate of the University of Cambridge.

Sørensen, T. (1948). A Method of Establishing Groups of Equal Amplitude in Plant Sociology Based on Similarity of Species and Its Application to Analyses of the Vegetation on Danish Commons. Biologiske Skrifter, 5, 1-34.

Sukardjo, S., Hagihara, A., Yamakura, T., \& Ogawa, H. (1990). Floristic Composition of a Tropical Rain Forest in Indonesian Borneo. Bulletin of the Nagoya University Forests, 
No. 10, 1-44.

Thein, H. M. (2007). Report on Flora Survey in Tanintharyi Nature Reserve, Myanmar (33 p.). Yangon: Forest Department, Ministry of Forestry, Union of Myanmar. (Unpublished)

Thu, Z. M. (2009). Dynamics and Management of Moist Evergreen Dipterocarp Forests in Mon State, Myanmar (110 p.). Master Thesis, Göttingen: Universität Göttingen.

Whitmore, T. C. (1984). Tropical Rain Forests of the Far East (2nd ed., 279 p.). Oxford: Oxford University Press.

Whitmore, T. C. (1998). An Introduction to Tropical Rain Forests. Oxford: Oxford University Press.

WWF (2002). Terrestrial Ecoregions of the Indo-Pacific: A Conservation Assessment.

Zin, I. I. S. (2017). Status and Management of Tanintharyi Nature Reserve, Tenasserim in Myanmar(275 p.). PhD Dissertation, Göttingen: Cuvillier Verlag. 